\title{
Lactobacillus acidophilus Probiotic Inhibits the Growth of Candida albicans
}

\author{
Sawitri D. Pertami ${ }^{1}$, Melkior Pancasiyanuar ${ }^{1}$, Sefy A. Irasari ${ }^{1}$, Markus B. Rahardjo², \\ Wasilah $^{2}$ \\ ${ }^{1}$ Undergraduate Program, Faculty of Dentistry, Institute of Health Science Bhakti Wiyata, Kediri 64114, Indonesia \\ ${ }^{2}$ Faculty of Dentistry, Institute of Health Science Bhakti Wiyata, Kediri 64114, Indonesia \\ Correspondence e-mail: japanese.turning@yahoo.co.id.
}

\begin{abstract}
Candida albicans is the most common organism causing oral candidiasis. Drug resistance to synthetic antifungal medication is becoming a problem in the treatment of oral candidiasis, especially in immunocompromised patients. Probiotic has been known for its health benefits. It produces lactic acid and bacteriocin that has antibacterial effect. Research focuses on antifungal effect of probiotic, escpecially for C. albicans is still needed. Objective: To determine the inhibition effect of probiotic in the growth of $C$. albicans. Methods: Three concentrations of Lactobacillus acidophilus-containing probiotic (McFarland 6, 8, 10) were used to determine their inhibition effect on C. albicans (McFarland 0.5) growing in trypticase yeast-extract cystine (TYC) agar. The inhibition effect of probiotic was determined by measuring the inhibition zone produced after 48 hours of culture. Difference in inhibition zone among experimental groups was analyzed using one-way ANOVA and LSD post-test. Results: Probiotic with McFarland 10 had the highest inhibition effect against $C$. albicans and the difference to other experimental groups was statistically significant $(p<0.05)$. Conclusion: L. acidophilus probiotic has inhibition effect in the growth of C. albicans.
\end{abstract}

\begin{abstract}
ABSTRAK
Daya hambat probiotik Lactobacillus acidhopilus terhadap pertumbuhan Candida albicans. Candida albicans (C.albicans) merupakan salah satu jamur yang sering menyebabkan kandidiasis oral. Resistensi obat kerap menjadi masalah dalam penatalaksanaan kandidiasis oral terutama pada pasien kompromis imun. Manfaat probiotik terhadap kesehatan telah diketahui secara luas. Probiotik memproduksi asam laktat dan bakteriosin yang mempunyai efek antibakteri. Namun penelitian yang berfokus pada efek antijamur probiotik, terutama untuk C. albicans masih dibutuhkan. Tujuan: Menganalisis efek hambatan pertumbuhan C. albicans setelah pemberian probiotik. Metode: Tiga konsentrasi probiotik yang mengandung Lactobacillus acidophilus (McFarland 6, 8, 10) digunakan untuk melihat efek hambatan terhadap pertumbuhan C. albicans (McFarland 0.5) yang ditumbuhkan pada agar trypticase yeast-extract cystine (TYC). Pengukuran zona hambat dilakukan setelah kultur selama 48 jam. Perbedaan zona hambat antara kelompok uji dianalisis dengan one-way ANOVA. Hasil: Probiotik dengan konsentrasi McFarland 10 mempunyai efek hambatan pertumbuhan yang paling tinggi terhadap C. albicans dan perbedaan ini bermakna jika dibandingkan dengan kelompok uji lain $(p<0.05)$. Simpulan: L. acidophillus probiotik mempunyai daya hambat terhadap pertumbuhan C.albicans.
\end{abstract}

Key words: Candida albicans, inhibition concentration, Lactobacillus acidophilus, probiotic

\section{PENDAHULUAN}

Jamur merupakan salah satu penyebab infeksi pada manusia. Jamur yang paling patogen dan sering menginfeksi manusia berasal dari genus Candida. ${ }^{1}$ Dalam rongga mulut, $70 \%$ infeksi Candida pada manusia disebabkan oleh Candida albicans. ${ }^{2}$ Infeksi $C$. albicans dalam rongga mulut disebut kandidiasis oral. ${ }^{3}$
Terapi terhadap kandidiasis oral masih mengalami permasalahan, disebabkan C. albicans menjadi resisten terhadap anti jamur sistemik yang sering digunakan. Diperlukan penelitian mengenai bahan baru yang efektif sebagai anti jamur, khususnya terhadap $C$. albicans. ${ }^{4}$ Salah satu bahan yang dapat digunakan 
sebagai anti jamur adalah probiotik. Probiotik mampu mempengaruhi prevalensi Candida pada silicone rubber voice protheses, dengan cara menghasilkan asam laktat dan bakteriosin yang mampu menghambat pertumbuhan Candida. ${ }^{5}$

Probiotik banyak tersedia di pasaran dengan bermacammacam kandungan, salah satunya $L$. acidophilus L. acidophilus banyak terdapat dalam produk susu fermentasi (yoghurt, buttermilk, dan susu asidofilus), pangan yang disuplementasi dan obat-obatan. ${ }^{1} L$. acidophilus merupakan salah satu bakteri penting yang terdapat di dalam saluran pencernaan, vagina, dan rongga mulut. ${ }^{6}$ L. acidophilus yang terkandung dalam probiotik memiliki efek antijamur dengan menghambat pertumbuhan jamur Aspergillus flavus dan Penicillium citrinum. ${ }^{6}$ Hingga saat ini penelitian tentang daya hambat probiotik terhadap pertumbuhan C. albicans belum sepenuhnya dilakukan. Penelitian ini bertujuan untuk mengetahui daya hambat probiotik L. acidophilus terhadap pertumbuhan $C$. albicans.

\section{METODE}

Jenis penelitian yang dilakukan adalah penelitian eksperimental laboratoris dengan rancangan penelitian Post Test Only Control Group Design. ${ }^{7}$ Penelitian ini menggunakan 6 sampel tiap perlakuan dalam satu kelompok. Jumlah total sampel dalam penelitian ini adalah 24. Probiotik dalam penelitian ini didapat dari produk suplemen probiotik (merk dagang A, produksi $\mathrm{N})$ yang berbentuk kapsul, dengan komposisi gellatin, selulose, whey powder, dan $3 \times 10^{8}$ L. acidophilus. Probiotik yang digunakan dalam penelitian ini memiliki standar McFarland $6\left(18 \times 10^{8} \mathrm{CFU} / \mathrm{ml}\right)$, McFarland $8\left(21 \times 10^{8} \mathrm{CFU} / \mathrm{ml}\right)$, dan McFarland 10 $\left(30 \times 10^{8} \mathrm{CFU} / \mathrm{ml}\right){ }^{8}$ Uji daya hambat menggunakan sistem difusi untuk mengetahui Minimum Inhibitory Concentration (MIC) yaitu konsentrasi terendah bahan yang mampu menghambat pertumbuhan $C$. albicans. C. albicans adalah jamur yang memiliki morfologi berupa yeast like cells atau blastospora, pseudohifa, dan klamidospora. Pertumbuhan C. albicans dalam penelitian ini ditandai dengan terbentuknya koloni jamur yang memiliki bau seperti ragi. ${ }^{9}$

Alat-alat yang akan digunakan dicuci sampai bersih, dikeringkan dan ditutup rapat dengan kertas. Alat yang telah dikeringkan, disterilisasi pada suhu $121^{\circ} \mathrm{C}$ selama lebih kurang 15 menit. ${ }^{10}$ Untuk menumbuhkan probiotik yang mengandung L. acidophilus, produk suplemen probiotik $\mathrm{N}$ dimasukkan ke dalam tabung reaksi yang berisi media BHIB, diinkubasi secara anaerob dalam anaerobic jar dan diinkubasi pada suhu $37^{\circ} \mathrm{C}$, selama 24 jam. L. acidophilus yang terbentuk diisolasi dengan mengambil koloni L. acidophilus dan dimasukkan ke dalam media agar TYC, dan diinkubasi secara anaerob pada suhu $37^{\circ} \mathrm{C}$, selama 24 jam. ${ }^{6}$ Koloni L. Acidophilus yang terbentuk dimasukkan ke dalam media BHIB, diinkubasi secara anaerob pada suhu $37^{\circ} \mathrm{C}$ selama 24 jam, untuk digunakan dalam pengukuran standar kekeruhan McFarland 6, 8, dan 10 yang akan digunakan dalam uji daya hambat.

Standarisasi $C$. albicans dilakukan dengan penanaman stok kultur C. albicans pada media Sabaroud Dextrose Agar ke dalam media Sabouraud Dextrose Broth, diinkubasi secara aerob pada suhu $37^{\circ} \mathrm{C}$, selama 24 jam. Kekeruhannya diukur dengan standar McFarland 0,5. C. albicans tumbuh diusapkan secara merata menggunakan cotton stick, pada seluruh permukaan media agar TYC, diinkubasi secara anaerob pada suhu $37^{\circ} \mathrm{C}$, selama 24 jam, untuk kemudian digunakan dalam uji daya hambat. ${ }^{11}$

Uji daya hambat dalam penelitian ini menggunakan tes difusi. C.albicans ditanam dalam media dengan melakukan swab secara merata pada permukaan media menggunakan cotton stick. Kertas saring dicelupkan menggunakan pinset ke dalam media BHIB yang berisi probiotik, dengan standar McFarland 6, tabung 2 dengan standar McFarland 8, tabung 3 dengan standar McFarland 10. Kertas saring berisi media BHIB tanpa probiotik digunakan sebagai kontrol. Setiap petridish yang sudah diberi probiotik ditutup dengan petridish yang tidak berisi media TYC. Kemudian semua petridish dimasukkan ke dalam anaerobic jar, yang berisi gas kit dan disimpan dalam inkubator pada suhu $37^{\circ} \mathrm{C}$, selama 48 jam. Diameter zona hambat probiotik terhadap pertumbuhan $C$. albicans yang terbentuk diukur dengan menggunakan jangka sorong dengan kepekaan $0,05 \mathrm{~mm} .^{12}$

\section{HASIL}

Uji daya hambat probiotik terhadap pertumbuhan $C$. albicans menunjukkan bahwa tidak ditemukan adanya daya hambat terhadap pertumbuhan $C$. albicans pada probiotik L. acidophilus dengan standar McFarland 6, 8 dan kelompok kontrol. Daya hambat terhadap pertumbuhan $C$. albicans terdapat pada probiotik $L$. acidophilus dengan standar McFarland 10. Hal ini dapat dilihat dari hasil pengukuran diameter zona hambat yang terbentuk, yaitu berupa daerah jernih di sekeliling kertas saring yang mengandung probiotik. Berdasarkan hasil pengukuran diameter zona bening, daya hambat probiotik terhadap pertumbuhan $C$. albicans setelah 48 jam, dapat diketahui bahwa zona bening hanya didapatkan pada probiotik dengan standar McFarland 10, dimana nilai rata-rata zona bening yang terbentuk adalah $8,24 \mathrm{~mm}$ (Tabel 1). Uji one-way ANOVA menunjukkan terdapat perbedaan bermakna antar kelompok uji $(p<0,05)$. 
Tabel 1. Hasil pengukuran diameter zona bening daya hambat probiotik terhadap pertumbuhan C. albicans setelah 48 jam

\begin{tabular}{ccccc}
\hline \multicolumn{4}{c}{ Diameter zona bening (mm) } \\
\cline { 2 - 5 } No. & Kelompok Perlakuan & \multicolumn{3}{c}{ Kelompok Kontrol } \\
\cline { 2 - 5 } & McFarland 6 McFarland & McFarland 10 & Kontrol (-) \\
\hline 1 & 0 & 0 & 8,3 & 0 \\
2 & 0 & 0 & 8,15 & 0 \\
3 & 0 & 0 & 8,45 & 0 \\
4 & 0 & 0 & 8,2 & 0 \\
5 & 0 & 0 & 8,25 & 0 \\
6 & 0 & 0 & 8,10 & 0 \\
$\overline{\mathrm{x}}$ & 0 & 0 & 8,24 & 0 \\
\hline
\end{tabular}

\section{DISKUSI}

Hasil penelitian menunjukkan pada sekeliling paper disk ditumbuhi oleh $C$. albicans, yang berwarna putih kekuningan, menyebar hingga ke seluruh cawan. Pada sekitar paper disk yang mengandung probiotik dengan standar McFarland $6\left(18 \times 10^{8} \mathrm{CFU} / \mathrm{ml}\right)$ dan McFarland $8\left(21 \times 10^{8} \mathrm{CFU} / \mathrm{ml}\right)$ tidak menunjukkan terbentuknya zona hambat pertumbuhan C. albicans. Zona hambat pertumbuhan $C$. albicans terbentuk di sekitar paper disk yang mengandung probiotik L. acidophillus dengan standar McFarland 10 (30x10 $\left.0^{8} \mathrm{CFU} / \mathrm{ml}\right)$. Kelompok kontrol dengan paper disk yang hanya mengandung BHIB steril, menunjukkan pertumbuhan $C$. albicans pada seluruh plate tanpa disertai adanya zona hambat. Penelitian ini menggunakan pengulangan sebanyak 6 kali. Hasil penelitian menunjukkan adanya daya hambat probiotik L.acidophilus, terhadap pertumbuhan C. albicans yaitu pada standar McFarland 10 .

Hasil penelitian ini sesuai dengan hasil penelitian sebelumnya yang menganalisis peran probiotik beberapa jenis Lactobacili dalam menghambat pertumbuhan Streptococcus mutans dan Candida. ${ }^{13}$ Penelitian tersebut menggunakan bakteri probiotik $L$. plantarum, L. rhamnosus, L. paracasei, L. reuteri, dan L. acidophilus dengan konsentrasi bakteri $10^{3}, 10^{5}, 10^{7}$, dan $10^{9} .{ }^{13}$ Hasil penelitian tersebut menunjukkan L. acidophilus mampu menghambat pertumbuhan C. albicans pada konsentrasi $10^{9}$. Hal ini berbeda dengan hasil penelitian lain, yang menggunakan beberapa bakteri Lactobacillus rongga mulut sebagai probiotik potensial, untuk menjaga kesehatan rongga mulut, termasuk dalam menghambat pertumbuhan C. albicans. ${ }^{14}$ Hasil penelitian tersebut menunjukkan bahwa $L$. acidophilus tidak dapat menghambat pertumbuhan $C$. albicans karena bakteriosin, asam laktat, dan hidrogen peroksida $\left(\mathrm{H}_{2} \mathrm{O}_{2}\right)$ yang dihasilkan L. acidophilus belum cukup mampu menghambat pertumbuhan C. albicans. ${ }^{14}$
Penelitian yang menganalisis mekanisme kerja $L$. acidophilus menyatakan bahwa bakteri ini memiliki bakteriosin berupa acidocin, lactacin B, lactacin $F$, dan bahan-bahan lain berupa asam laktat dan $\mathrm{H}_{2} \mathrm{O}_{2}$. Mekanisme kerja bakteriosin terhadap jamur sama halnya dengan mekanisme bakteriosin terhadap bakteri. ${ }^{15}$ Target kerja bakteriosin adalah membran sitoplasma sel $C$. albicans yang sensitif, karena reaksi awal adalah merusak permeabilitas membran dan menghambat produksi energi, biosintesis protein, dan asam nukleat. Kontak antara bakteriosin dengan membran sel mengakibatkan gangguan potensial membran berupa destabilitas membran sitoplasma, sehingga sel menjadi tidak kuat, ketidakstabilan ini memberikan dampak berupa pembentukan lubang atau pori pada sel, sehingga terjadi kebocoran pada membran sitoplasma, yang memberikan efek berupa pertumbuhan sel yang terhambat atau mati. ${ }^{16}$

Asam laktat yang dihasilkan L. acidophilus juga dapat mengganggu keseimbangan asam-basa $C$. albicans. Keseimbangan asam-basa pada $C$. albicans ditunjukkan dengan $\mathrm{pH}$ yang mendekati normal. Interaksi dengan asam laktat akan menyebabkan perubahan $\mathrm{pH}$ pada protein dinding sel C. albicans, lapisan fosfolipid pada membran sel $C$. albicans, serta asam nukleat $C$. albicans. Hal ini akan mengakibatkan terganggunya keseimbangan asam-basa dan perubahan permeabilitas. Perubahan permeabilitas membran akan menghasilkan efek ganda, yaitu mengganggu transpor nutrisi ke dalam sel dan menyebabkan metabolit internal keluar dari sel, yang akhirnya akan menyebabkan kerusakan sel. ${ }^{15}$

C. albicans sebenarnya juga memiliki aktivitas antibakteri dengan menghasilkan killer toxin, untuk melawan bakteri gram positif tertentu termasuk bakteri L. acidophilus, tetapi aktivitas killer toxin yang dimiliki $C$. albicans kurang begitu kuat, apabila dibandingkan bakteriosin yang dihasilkan oleh $L$. acidophilus. ${ }^{9} \mathrm{Hal}$ ini terbukti dari hasil penelitian eksperimental laboratoris ini, yang menunjukkan adanya daya hambat probiotik L. acidophilus, terhadap pertumbuhan C. albicans setelah pemberian probiotik dengan standar McFarland 10.

\section{SIMPULAN}

Probiotik L. acidophilus mempunyai daya hambat terhadap pertumbuhan C. albicans.

\section{REFERENSI}

1. Hasslöf P, Hedberg M, Twetman S, Stecksén-Blicks C. Growth inhibition of oral mutans streptococci and candida by commercial probiotic lactobacilli-an in vitro study. BMC Oral Health. 2010;10:18. 
2. Moran GP, Coleman DC, Sullivan DJ. C. albicans versus $C$. dubliniensis: Why is $C$. albicans more pathogenic? Int J Microbiol. 2012; 5:1-7.

3. Samaranayake, L. 2002. Essential Microbiology for dentistry. 3rd ed. Philadelphia: Elsevier; 2002.

4. Williams D, Lewis M. Pathogenesis and treatment of oral candidosis. J Oral Microbiol. 2011;3:1-14.

5. van der Mei HC, Free RH, Elving GJ, van Weissenbruch R, Albers FWJ, Busscher HJ. Effect of probiotic bacteria on prevalence of yeast in oropharingeal biofilms on silicone rubber voice prostheses in vitro. J Med Microbiol. 2000; 49:713-8.

6. Kumar N, Narayanan R, Kavitha N, Dhanalakshmi B. Plasmid profile of lactic acid bacteria with antifungal properties. As J Food Ag-Ind. 2010;3:229-35.

7. Notoatmodjo S. Metodologi penelitian kesehatan. Jakarta: Rineka Cipta; 2010. Indonesian.

8. Toma MM, Pokrotnieks J. Probiotics as functional food: microbiological and medical aspects. Acta Univ Latviensis. 2006; 710:117-29.

9. Samaranayake L and Macfarlane TW. Oral candidiasis. London: Wright. 1990.

10. Rizki FY. Uji aktivitas antibakteri ekstrak methanol bunga Rosella (Hibiscus sabdarifa L.) terhadap bakteri Eschericia coli dan Stapylococcus aureus [undergraduate thesis]. Medan: Universitas Sumatera Utara; 2010. Indonesian.
11. Kuriyama TD, Ready DW, Williams J, Bagg MAO, Lewis WA, Coulter. In vitro susceptibility of oral Candida to seven antifungal agents. J Oral Microbiol Immunol. 2005; 20:349-53.

12. Fenny M. Uji Efektifitas antibakteri ekstrak teh hijau dan ekstrak daun sirih terhadap Streptocococcus viridans [undergraduate thesis]. Surabaya: Universitas Airlangga; 2006. Indonesian.

13. Keller MK, Hasslöf P, Stecksen-Blicks C, Twetman S. Co-aggregation and growth inhibition of probiotic lactobacilli and clinical isolates of mutans streptococci: an in vitro study. Acta Odontol Scan. 2011;1-6.

14. Koll P, Mandar R, Marcotte H, Leibur E, Mikelsaar M. Characterization of oral lactobacilli as potential probiotics for oral health. Oral Microl Immunol. 2008;9:139-47.

15. Parada JL, Caron CR, Medeiros ADP, Soccol CR. Bacteriocins from lactic acid bacteria: purification, properties and use as biopreservatives. Braz Arch Biol Tech. 2007;50:521-42.

16. Winarsa, R. Daya kerja filtrat biakan hidup Lactobacillus casei subspecies Shirota terhadap pertumbuhan Salmonella thypimurium, Shigella flexneri dan Eschericia coli in vitro [thesis]. Surabaya: Universitas Airlangga, 1999. Indonesian. 